University of Nebraska - Lincoln

DigitalCommons@University of Nebraska - Lincoln

\title{
Two Soybean Plant Introductions Display Slow Leaf Wilting and Reduced Yield Loss under Drought
}

\author{
S. M. Pathan \\ University of Missouri \\ J.-D Lee \\ Kyungpook National University Daegu \\ D. A. Sleper \\ University of Missouri Columbia, sleperd@missouri.edu \\ F. B. Fritschi \\ University of Missouri Columbia, FritschiF@missouri.edu \\ R. E. Sharp \\ University of Missouri Columbia, sharpr@missouri.edu
}

See next page for additional authors

Follow this and additional works at: https://digitalcommons.unl.edu/usdaarsfacpub

Pathan, S. M.; Lee, J.-D; Sleper, D. A.; Fritschi, F. B.; Sharp, R. E.; Carter, T. E. Jr.; Nelson, R. L.; King, C. A.; Schapaugh, W. T.; Ellersieck, M. R.; Nguyen, H. T.; and Shannon, J. G., "Two Soybean Plant Introductions Display Slow Leaf Wilting and Reduced Yield Loss under Drought" (2014). Publications from USDA-ARS / UNL Faculty. 1440.

https://digitalcommons.unl.edu/usdaarsfacpub/1440

This Article is brought to you for free and open access by the U.S. Department of Agriculture: Agricultural Research Service, Lincoln, Nebraska at DigitalCommons@University of Nebraska - Lincoln. It has been accepted for inclusion in Publications from USDA-ARS / UNL Faculty by an authorized administrator of DigitalCommons@University of Nebraska - Lincoln. 


\section{Authors}

S. M. Pathan, J.-D Lee, D. A. Sleper, F. B. Fritschi, R. E. Sharp, T. E. Carter Jr., R. L. Nelson, C. A. King, W. T. Schapaugh, M. R. Ellersieck, H. T. Nguyen, and J. G. Shannon 


\title{
Two Soybean Plant Introductions Display Slow Leaf Wilting and Reduced Yield Loss under Drought
}

\author{
S. M. Pathan ${ }^{1}$, J.-D. Lee ${ }^{2}$, D. A. Sleper ${ }^{3}$, F. B. Fritschi ${ }^{3}$, R. E. Sharp ${ }^{3}$, T. E. Carter Jr. ${ }^{4}$, R. L. Nelson ${ }^{5}$, \\ C. A. King ${ }^{6}$, W. T. Schapaugh ${ }^{7}$, M. R. Ellersieck ${ }^{8}$, H. T. Nguyen ${ }^{3}$ \& J. G. Shannon ${ }^{1}$ \\ 1 Division of Plant Sciences, University of Missouri-Fisher Delta Research Center Portageville, MO, USA \\ 2 School of Applied Biosciences, Kyungpook National University Daegu, Korea \\ 3 Division of Plant Sciences, University of Missouri Columbia, MO, USA \\ 4 Soybean and Nitrogen Fixation Research, USDA-ARS Raleigh, NC, USA \\ 5 Soybean/Maize Germplasm, Pathology and Genetics Research, USDA-ARS Urbana, IL, USA \\ 6 Department of Crop, Soil and Environmental Sciences, University of Arkansas Fayetteville, AR, USA \\ 7 Agronomy Department, Kansas State University Manhattan, KS, USA \\ 8 Collage of Agriculture, Food and Natural Resources, University of Missouri Columbia, MO, USA
}

\section{Keywords}

drought; drought tolerance; leaf wilting;

plant Introduction; soybean

\author{
Correspondence \\ J. G. Shannon \\ Division of Plant Sciences \\ University of Missouri-Fisher Delta Research \\ Center \\ Portageville \\ MO 63873, USA \\ Tel.: 1-573-379-5431 \\ Fax: 1-573-379-5875 \\ Email: shannong@missouri.edu
}

S. Pathan and J-D Lee contributed equally to
the article.

Accepted January 27, 2014

doi:10.1111/jac. 12053

\begin{abstract}
Due to high costs of irrigation, limited availability of irrigation water in many locations and/or lack of irrigation capabilities, genetic improvement for drought tolerance is an effective method to reduce yield loss in soybean [Glycine max (L.) Merr.]. Slow wilting and minimal yield reduction under drought are important traits in evaluating drought tolerance. Two maturity group III soybean plant introductions (PIs, PI 567690 and PI 567731) and two elite cultivars (DKB38-52 and Pana) were evaluated with and without irrigation on a sandy soil. Drought was imposed by withholding irrigation at full bloom and continued until moderate wilting was shown by the fast leaf wilting in the check cultivar, Pana. Then, irrigation was resumed until maturity. Genotypes were scored for leaf wilting during the stress period, and yields were assessed at the end of the growing season and used to calculate a drought index. Yields of the exotic PIs were lower than those of the checks under both drought and well-watered conditions. However, the PIs exhibited significantly lower wilting and less yield loss under drought (higher drought index) than check cultivars. The two PIs may have useful genes to develop drought-tolerant germplasm and cultivars and maybe useful in genetic and physiological studies to decipher mechanisms responsible for improving yield under limited water availability.
\end{abstract}

\section{Introduction}

Drought is the most important abiotic stress limiting soybean yield (Specht et al. 1999, Purcell and Specht 2004). Drought tolerance has been identified as a major target area for crop improvement (Pennisi 2008). Soybean production generally depends on natural rainfall, but uneven distribution of rainfall (too much or too little) causes year-to-year yield variation in the same field. Soybean is highly susceptible to drought, particularly in the reproductive growth stage (Oya et al. 2004). Due to high costs of irrigation and/ or lack of water availability, irrigation is not a feasible option for most of the soybean growing regions in the USA and in other soybean-producing countries of the world. Therefore, genetic improvement for drought tolerance is a cost-effective approach to limit soybean yield loss under non-irrigated conditions. Genetic diversity among US soybean cultivars for yield under drought has been reported (Mederski and Jeffers 1973, Specht et al. 1986). However, Carter et al. (2006) reported little variation for drought tolerance among US soybean cultivars. According to King et al. (2009), little conscious selection pressure has been applied by breeders to improve drought tolerance in soybean. Generally, breeders select for yield under favourable, high yielding environments. However, identification of drought-tolerant germplasm requires screening in 
unfavourable environments where water stress is common and yields are low.

Plants use different physiological traits to cope with drought stress. Major traits include slow canopy wilting, sustained nitrogen fixation under drought, increased water use efficiency, deeper taproots, fibrous lateral roots, osmotic adjustment and antioxidant capacity (Manavalan et al. 2009, 2010). In soybean, slow canopy wilting and sustained nitrogen fixation under drought have resulted in yield increases under water-limited environments (Sinclair et al. 2007). Canopy wilting is the first visible symptom of water stress, and a number of genotypes have been identified as slow wilting under field conditions (Carter et al. 1999, 2006). Scientists at North Carolina identified several soybean plant introductions (PIs) and developed breeding lines which wilt more slowly than existing cultivars. Two PIs, PI 416937 and PI 471938, and two breeding lines, N94-7784 and NTCPR94-5157 are slow wilting and drought tolerant (Carter et al. 1999, 2006). Inheritance of the slow wilting trait is polygenic (Charlson et al. 2009). Thus, several mechanisms are likely to be responsible for slow wilting in PI 416937 (King et al. 2009). Research shows that PI 416937 has a prolific rooting system (Carter et al. 2007, 2008), which includes an extensive lateral root system (Goldman et al. 1989, Sloane et al. 1990, Hudak and Patterson 1996) and higher root surface area (Pantalone et al. 1996). Five QTL have been identified for enhanced fibrous roots under drought (Abdel-Haleem et al. 2010).

Nitrogen fixation in soybean is sensitive to soil drying (Sinclair and Serraj 1995, Serraj et al. 1999). Under drought, soybean cultivars generally exhibit decreased nitrogen fixation rates prior to declines of other physiological activities (Sinclair 1986, Serraj and Sinclair 1997) and this in turn slows seed production due to inadequate supply of nitrogen and finally results in reduced yield (Purcell and King 1996, Sinclair et al. 2007). Purcell and King (1996) and Ray et al. (2006) estimated the effect of nitrogen fixation sensitivity to drought under field conditions by applying mineral nitrogen fertilizer to water-limited plants. In contrast to water-limited soybeans that did not receive mineral fertilizer nitrogen, those that were fertilized with mineral nitrogen produced 15-20\% higher yields. Soil drying leads to accumulation of ureides in soybean leaves and is associated with reduced nitrogen fixation activity (de Silva et al. 1996, Serraj et al. 1999). Plants that accumulate more ureides in leaves exhibit lesser nitrogen fixation (Vadez et al. 2000), while plants that accumulate lower ureide levels in leaves show increased nitrogen fixation under drought (Sall and Sinclair 1991, Serraj and Sinclair 1997, Sinclair et al. 2007). Recently, scientists at the University of Arkansas developed and released two soybean lines, R01-416F and R01-581F with high yield potential and sustained nitrogen fixation capacity under moderate drought conditions (Chen et al. 2007). They are also working to combine both prolonged nitrogen fixation and delayed wilting into improved cultivars to better withstand droughts (Sinclair et al. 2007).

King and Purcell (2001) conducted a study to examine the relationship between nodule size and nitrogen fixation response under drought using the drought-tolerant cultivar 'Jackson', with larger nodules, and the drought sensitive cultivar 'KS4895', with smaller nodule size. They concluded that large nodules would favour photosynthate and water allocation, maintain higher relative water content and provide continuous water supply for export of ureides in the nodule xylem. Pantalone et al. (1996) also reported that the slow wilting line PI 416937 had greater nodule number and nodule dry weight compared with sensitive genotypes. This PI also has greater biological nitrogen fixation capacity at mid-pod fill stage than the cultivar 'Forrest' (Marlow 1993).

Evaluation of more soybean genotypes for drought tolerance under field conditions should accelerate breeding progress. However, evaluation of drought tolerance under field conditions is high risk and difficult in that drought is unpredictable as to when and where it will occur (Carter et al. 1999, 2006). Thus, a field with poor moisture holding capacity, good soil uniformity and a reasonable probability of drought each year is important in selecting genotypes for drought tolerance.

Soybean varieties are grouped into different maturity group (MG) depending on climate and latitude for which they are adapted. The MGs number 00,0 and I being adapted for the northern US; MGs II, III and early IV to the central US; MGs late IV and V for the mid-south; and MGs VI, VII and VIII being grown in the extreme southern United States. Different researchers have identified drought-tolerant PIs and breeding lines, especially in MG $\mathrm{V}$ and later MGs adapted to lower latitudes or the southern United States, and have used them to develop droughttolerant soybean germplasm. However, few studies have been conducted to evaluate plant introductions in MGs II, III and IV for drought tolerance. Varieties in these maturities are predominate in mid-western states such as Kansas, Kentucky, Nebraska, Missouri, Iowa, Illinois, Indiana and Ohio which account for about $60 \%$ of US planted acreage (www soystats.com).

Based on leaf wilting scores and yield loss under drought, two MG III PI's, PI 567690 and PI 567731, were identified as drought tolerant in southern Missouri trials. The purpose of this study was to compare these two exotic MG III PIs with two MG III check cultivars, for drought tolerance based on lower yield reduction under drought compared with well-watered conditions and slower wilting under reduced soil moisture. 


\section{Materials and Methods}

\section{Plant materials}

Two hundred and fifty (250) soybean MG III PIs originating from 'wet' (176 PIs) and 'dry' areas (74 PIs) of China, Korea and Japan were selected based on regional climate data. They were evaluated for reduced leaf wilting and yield loss under drought from 2003 to 2005 . Based on these two characteristics, PI 567690 and PI 567731 were identified as the most drought tolerant. These accessions are both from Anhui province, China, and were received from Institute of Crop Germplasm Resources, Beijing, China in 1992. Anhui was originally selected as a 'wet' province but according to data from the China, Meteorological Administration annual precipitation in the province ranges from 800 to $1600 \mathrm{~mm}$ from north to south (Deng et al. 2006). According to information from the Institute of Crop Germplasm Resources, the records for soybean germplasm in Anhui were lost in the 1960s so information that could more precisely define the origin of these introductions is not available. These two PIs and two elite check varieties, Pana, observed to be fast wilting and DKB38-52, a widely grown MG III variety developed by Monsanto Inc., were further evaluated for tolerance by testing them under drought and also with full season irrigation for 5 years: 2006, 2008, 2009, 2010 and 2011.

\section{Methods}

The PIs and checks were planted on a Dundee sandy loam (Aeric Ochraqualfs) located at the University of MissouriDelta Research Center Rhodes Farm near Clarkton, MO. The four entries were grown in three replications within each of two irrigation regimes. Irrigation regimes were located adjacent to each other within the same field.

Irrigation levels included full irrigation throughout the growing season (termed as irrigated field) and the other with interrupted irrigation to induce drought stress (termed as drought-stressed field). The four soybean genotypes PI 567690 and PI 567731 and two checks, DKB38-52 and Pana, were subplots. Four-row plots $(0.76 \mathrm{~m}$ row distance) were $3.7 \mathrm{~m}$ long, and 36 seeds were planted per metre of row. Alleys $1.2 \mathrm{~m}$ in width were maintained between plots. Sowing was conducted each year between 9 May and 20 May depending on field conditions. In the drought treatment, stress was imposed at full bloom (R2 growth stage) by withholding irrigation and continued until the plants of the drought sensitive check (Pana) were moderately to severely stressed. Depending on the year, the stress period lasted for 3-4 weeks or until about beginning seed development (R5) (Fehr and Caviness 1977). Leaf wilting was rated in the stress treatment when the fast wilt- ing check (Pana) showed stress at late morning or mid-day. Data were recorded for leaf wilting on a 1-5 scale (score 1 = no wilting, 2 = few top leaves showed wilting, $3=$ half of the leaves showed wilting, $4=$ severe wilting, about $75 \%$ of the leaves showed wilting and $5=$ severely wilted and plant death). In the summer of 2010, the two PIs and the checks were also evaluated for leaf wilting at Salina, KS. After imposing stress, irrigation was resumed to prevent plant death and to continue plant growth to maturity. At maturity, middle two rows of each plot were harvested from irrigated and stressed treatments using a plot combine to compare yields from well-watered and drought stresses treatments. A drought index was calculated by diving yield under drought by yield under irrigation and multiplication by 100 .

\section{Data analysis}

Data for yield (irrigated and drought-stressed plots), leaf wilting score and drought index were subjected to analysis of variance (ANOVA) as a split plot design using PROC MIXED in SAS version 9.2 (SAS Institute 2002). The linear statistical model contains the effect of environment (year), replication within environment, genotype and genotype $\times$ environment interaction. Year, genotype and genotype $\times$ environment (year) were considered as fixed and replication within environment were considered as random effect. The effect of year was tested using replication within year as the denominator of F. Mean differences were determined using Fisher's least significant difference (LSD).

\section{Results}

Although less productive, both PI 567690 and PI 567731 had similar maturity, yellow seed coat colour, higher protein and slightly lower oil content in comparison with the two check cultivars (Table 1). Analyses of variance (ANOvA) results for irrigated yield, drought yield, drought index and leaf wilting score are presented in Table 2. Year effects for drought yield and wilting score were not significant, whereas year effects were significant for irrigated yield and drought index. A significant genotype effect was found for all traits. In contrast, year $\times$ genotype interactions were not significant. Therefore, analyses for variable means were combined over years. Means for drought yield, irrigated yield, drought index and wilting scores across 5 years are shown in Table 3. As expected, the two exotic PIs yielded less than the two elite cultivars under both irrigated and drought-stressed conditions. However, the average yield loss under drought compared with the well-watered conditions for the PIs was less than the corresponding yield loss for the checks. This is shown by the greater drought indexes for the PIs compared with the checks. The average drought 
Table 1 Origin, agronomic traits and seed composition of two plant introductions and two check varieties evaluated under drought and irrigation over 5 years 2006, 2008, 2009, 2010 and 2011, Clarkton, MO

\begin{tabular}{|c|c|c|c|c|c|c|}
\hline Genotype & Origin & Height (cm) & Maturity date & Seed weight ${ }^{1}$ & $\begin{array}{l}\text { Protein } \\
\left(\mathrm{g} \mathrm{kg}^{-1}\right)^{2}\end{array}$ & $\begin{array}{l}\text { Oil } \\
\left(\mathrm{g} \mathrm{kg}^{-1}\right)^{2}\end{array}$ \\
\hline PI 567690 & Anhui, China & 98 & Sept. 15 & 12.3 & 420 & 210 \\
\hline PI 567731 & Anhui, China & 92 & Sept. 15 & 13.2 & 414 & 209 \\
\hline DKB38-52 & USA & 80 & Sept. 17 & 12.5 & 390 & 222 \\
\hline Pana & USA & 89 & Sept. 16 & 11.7 & 400 & 222 \\
\hline
\end{tabular}

'g per 100 seed.

${ }^{2} \mathrm{~g}$ per kg on dry matter basis.

Table 2 Analysis of variance of drought-stressed and irrigated yield, drought index and leaf wilting score at University of Missouri Fisher Delta Research Center Rhodes Farm, 2006, 2008, 2009, 2010 and 2011, Clarkton, MO

\begin{tabular}{llllll}
\hline Source of variation & Degrees of freedom score & Drought yield & Irrigated yield & Drought index & Wilting \\
\hline Year & 4 & $0.09 \mathrm{~ns}$ & $0.05^{*}$ & $0.005^{* *}$ & $0.7 \mathrm{~ns}$ \\
Genotype & 3 & $0.001^{* * *}$ & $0.0001^{* * *}$ & $0.004^{* *}$ & $0.0006^{* * *}$ \\
Year $\times$ genotype & 12 & $0.08 \mathrm{~ns}$ & $0.2 \mathrm{~ns}$ & $0.15 \mathrm{~ns}$ & $0.3 \mathrm{~ns}$ \\
\hline
\end{tabular}

${ }^{1}$ Drought index $=$ (yield under drought/yield under irrigation) $\times 100$.

${ }^{2}$ PI 567690, PI 567731, DKB38-52 and Pana.

*Significant at the 0.05 probability level.

** Significant at the 0.01 probability level.

$* * *$ Significant at the 0.001 probability level.

ns, not significant $(P=0.05)$.

indexes of the two drought-tolerant lines, PI 567690 and PI 567731, were 92 and 88, respectively. The drought indexes of check cultivars DKB38-52 and Pana were 68 and 75, respectively (Table 3 ). Average wilting scores of the two drought-tolerant PIs, PI 567690 and PI 567731 were 1.6 and 1.8, respectively. The check cultivars DKB38-52 and Pana showed higher wilting scores of 2.7 and 3.1, respectively (Table 3 ).

In 2010, the four genotypes were also evaluated for leaf wilting at Salina, KS. Wilting was rated using a rating scale from $0 \mathrm{t} 100$ with $0=$ no wilting, $40=$ moderate wilting, $60=$ severe wilting and $100=$ plant death (King et al. 2009). Wilting scores were recorded on 29 July 2010 and 10 August 2010. The drought-tolerant lines, PI 567690 and PI 567731, had significantly lower wilting scores than the drought sensitive checks DKB38-52 and Pana. On 29 July, wilting scores of two PIs, DKB38-52 and Pana were 28, 32, 37 and 38, respectively, and on 10 August, wilting scores of two PIs, DKB38-52 and Pana were 38, 38, 39 and 47, respectively.

\section{Discussion}

The general notion exists that drought-tolerant plant accessions would most likely originate from drier rather than more humid climates. However, the two soybean accessions used in this study, selected out of 250 lines, that exhibited
Table 3 Mean drought yield, irrigated yield, drought index and leaf wilting score for maturity group III accessions PI 567690, PI 567731 and two check cultivars DKB38-52 and Pana grown over 5 years 2006, 2008, 2009, 2010 and 2011 at the University of Missouri Fisher Delta Research Center Rhodes Farm, Clarkton, MO

\begin{tabular}{|c|c|c|c|c|}
\hline Genotype & $\begin{array}{l}\text { Drought yield } \\
\mathrm{kg} \mathrm{ha}^{-1}\end{array}$ & $\begin{array}{l}\text { Irrigated yield } \\
\mathrm{kg} \mathrm{ha}^{-1}\end{array}$ & $\begin{array}{l}\text { Drought } \\
\text { index }^{1}\end{array}$ & $\begin{array}{l}\text { Wilting } \\
\text { score }\end{array}$ \\
\hline PI 567690 & $1283 b^{2}$ & $1389 b$ & $92.4 a$ & $1.6 b$ \\
\hline PI 567731 & $1165 b$ & $1326 b$ & $88.0 a$ & $1.8 b$ \\
\hline DKB38-52 & $1545 a$ & $2274 a$ & $67.9 b$ & $2.7 a$ \\
\hline Pana & $1713 a$ & $2287 a$ & $74.9 \mathrm{~b}$ & $3.1 \mathrm{a}$ \\
\hline$C V$ & 20.7 & 21.1 & 18.4 & 23.3 \\
\hline $\operatorname{LSD}_{(0.05)}$ & 258 & 338 & 12.9 & 0.6 \\
\hline
\end{tabular}

${ }^{1}$ Drought index $=($ ratio of yield under drought $\div$ yield under irrigation) $\times 100$.

${ }^{2}$ Means with the same letter within a column for a given measurement are not significantly different as determined by Fisher's LSD $(P=0.05)$.

the most consistent drought tolerance originated from a humid region of China. This indicates that the climate of the origin region is not necessarily a good predictor of drought-tolerant germplasm.

Yields, drought indexes and leaf wilting scores of four genotypes were evaluated under irrigated and droughtstressed conditions. No significant year by genotype effects was observed, indicating that the responses of the 
genotypes were consistent across the 5 years of this study. However, while yields under drought and wilting scores were not significantly different between years, yields under irrigated conditions and, consequently, drought index were significantly influenced by year. Significant differences between genotypes were found for all traits (Table 2), and the responses of the two PIs (PI 567690 and PI 567731) were distinct from those of the two check genotypes (DKB38-52 and Pana).

We used term 'drought index' for the first time. It was calculated by diving yield under drought by yield under irrigation and multiplication by 100 . Minimum yield differences of a genotype between irrigated field and droughtstressed plots (higher drought index) may serve as a useful criterion in considering drought tolerance among genotypes. As expected, yields of the exotic PIs were lower than those of the cultivars in both stressed and irrigated field conditions. Greater yield differences of the check cultivars were associated with a more pronounced effect of the drought treatment, causing in bigger yield losses in the check cultivars than in the PIs (Table 3). Yield differences of PIs between irrigated and stressed field conditions ranged from about 100 to $160 \mathrm{~kg} \mathrm{ha}^{-1}$, while those of check cultivars ranged from about 575 to $700 \mathrm{~kg} \mathrm{ha}^{-1}$. Thus, on average, yield of PI 567690 under stress was only $8 \%$ lower than under full irrigation, and yield of PI 567731 under drought was only $12 \%$ lower than under full irrigation. In contrast, yields were $32 \%$ and $25 \%$ lower in stressed compared with fully irrigated treatments for DKB38-52 and Pana, respectively (Table 3 ). The greater impact of the drought treatment on the check cultivars than the PIs may indicate that the PIs are more drought tolerant than the check cultivars and may be useful sources for genes underlying yield stability.

As indicated by a significant negative correlation $(-0.31)$ between drought index and leaf wilting score, better drought indexes of PI 567690 and PI 567731 compared with the check cultivars were associated with lower wilting scores (Table 3). Slower wilting is expected to be associated with prolonged carbon fixation and growth and may underlay the lower yield reductions of the PIs than the check cultivars in response to drought. Although the scale for wilting score was different at Kansas study, the general ranking of wilting scores (from low to high) among four genotypes was consistent. The two PIs had lower wilting scores than the two check cultivars. In the same experiment, the most studied drought-tolerant soybean genotype PI 416937 had a similar wilting score to PI 567690 on 29 July, but PI 416937 had higher score on 10 August.

In 2011, soil moisture was monitored at 10, 20, 30, 40, 60 and $100 \mathrm{~cm}$ soil depth for each genotype just before recording wilting score. Under drought, PI 567690, PI 567731 and Pana had similar soil moisture contents at a
10-20 cm depth, but Pana had significantly lower moisture content at 30-40 cm depth than the PIs (data not shown). This indicated that Pana absorbed more water from 30 to $40 \mathrm{~cm}$ depth than the PIs during drought stress. Soil moisture content at $60-100 \mathrm{~cm}$ depth was similar for all genotypes. Leaf relative water contents (RWC) were similar between PIs and Pana for the control plots but was higher in PIs than Pana during water stress.

In this 5-year study, yield reductions under stressed compared with irrigated conditions were lower and were associated with slower wilting of the PIs compared with the check cultivars. However, the functional linkage between the slow wilting phenotype and greater drought index was not investigated in this study. Nonetheless, the results of this study indicated that the two MG III PIs may be useful in breeding programs aimed at enhancing drought tolerance. Further studies are needed to elucidate the genetics and physiological mechanisms underlying the responses of these two PIs under drought.

\section{Acknowledgements}

The authors wish to thank the Missouri Soybean Merchandizing Council (MSMC) and the United Soybean Board (USB) for the financial support for this research.

\section{References}

Abdel-Haleem, H., G.-D. Lee, T. E. Jr Carter, and R. Boerma, 2010: Fibrous root as avoidance mechanism for drought resistance in soybean: identification of fibrous rooting QTLs. Poster abstract at: 13th Biennial Molecular and Cellular Biology of Soybean Conference, Durham, NC, USA, August 8-10, 2010.

Carter, T. E. Jr, P. I. De Souza, and L. C. Purcell,1999: Recent advances in breeding for drought and aluminum resistance in soybean. In: H. Kauffman, ed. Proceedings of the sixth World Soybean Research Conference, Chicago, IL, pp. 106-125. Superior Printing, Champaign, IL.

Carter, T. E. Jr, J. Orf, L. C. Purcell, J. Specht, H. R. Boerma, P. Chen, T. Sinclair, and T. Rufty, 2006: Tough times, tough plants - new soybean genes defend against drought and other stresses. In: Proceedings of the 33rd Soybean Seed Research Conference, Chicago, IL, 5-8 Dec. 2006.

Carter T. E. Jr, J. W. Burton, M. O. Fountain, P. E. Rzewnicki, M. R. Villagarcia, and D. T. Bowman, 2007: Registration of 'N7002' soybean. J. Plant Reg. 1, 93-94.

Carter T. E. Jr, J. W. Burton, M. O. Fountain, P. E. Rzewnicki, M. R. Villagarcia, and D. T. Bowman, 2008: Registration of 'N8001' soybean. J. Plant Reg. 2, 22-23.

Charlson, D. V., S. Bhatnagar, C. A. King, J. D. Ray, C. H. Sneller, T. E. Jr Carter, and L. C. Purcell, 2009: Polygenic inheritance of canopy wilting in soybean [Glycine max, (L.) Merr.]. Theor. Appl. Genet. 119, 587-594. 
Chen, P., C. H. Sneller, L. C. Purcell, T. R. Sinclair, C. A. King, and T. Ishibashi, 2007: Registration of soybean germplasm lines R01-416F and R01-581F for improved yield and nitrogen fixation under drought stress. J. Plant Reg. 1, 166-167.

Deng, X.-P., L. Shan, H. Zhang, and N. C. Turner. 2006: Improving agricultural water use efficiency in arid and semiarid areas of China. Agr. Water Manage. 80, 23-40.

Fehr, R. W., and C. E. Caviness, 1977: Stages of soybean development. Spec. Rep. 80. Iowa State Univ. Coop. Ext. Serv., Ames.

Goldman, I. L., T. E. Jr Carter, and R. P. Patterson, 1989: Differential response to drought stress and subsoil aluminum in soybean. Crop Sci. 29, 330-334.

Hudak, C. M., and P. R. Patterson, 1996: Root distribution and soil moisture depletion pattern of a drought-resistant soybean plant introduction. Agron. J. 88, 478-485.

King, C. A., and L. C. Purcell, 2001: Soybean nodule size and relationship to nitrogen fixation response to water deficit. Crop Sci. 41, 1099-1107.

King, C. A., L. C. Purcell, and K. R. Brye, 2009: Differential wilting among soybean genotypes in response to water deficit. Crop Sci. 49, 290-298.

Manavalan, L. P., S. K. Guttikonda, L.-S. P. Tran, and H. T. Nguyen, 2009: Physiological and molecular approaches to improve drought resistance in soybean. Plant Cell Physiol. 50, 1260-1276.

Manavalan, L. P., S. K. Guttikonda, V. T. Nguyen, J. G. Shannon, and H. T. Nguyen, 2010: Evaluation of diverse soybean germplasm for root growth and architecture. Plant Soil 330, 503-514.

Marlow, W. S., 1993: Canopy apparent photosynthesis and biological nitrogen fixation of a drought tolerant soybean genotype. M.S. thesis, North Carolina State Uninv., Raleigh, NC.

Mederski, H. J., and D. L. Jeffers, 1973: Yield response of soybean varieties grown at two soil moisture levels. Agron. J. 65, 410-412.

Oya, T., A. L. Nepomuceno, N. Numaier, J. R. B. Farias, S. Tobita, and S. Ito, 2004: Drought tolerance characteristics of Brazilian cultivars - evaluation and characterization of drought tolerance of various Brazilian soybean cultivars in the field. Plant Prod. Sci. 7, 129-137.

Pantalone, V. R., G. J. Rebetzke, J. W. Burton, and T. E. Carter Jr, 1996: Phenotypic evaluation of root traits in soybean and applicability to plant breeding. Crop Sci. 36, 456-459.

Pennisi, E., 2008: The blue revolution, drop by drop, gene by gene. Science 320, 171-173.
Purcell, L. C., and C. A. King, 1996: Drought and nitrogen source effects on nitrogen nutrition, seed growth, and yield in soybean. J. Plant Nutr. 19, 969-993.

Purcell, L. C., and J. E. Specht, 2004: Physiological traits for ameliorating drought stress. In: H. R. Boerma, and J. E. Specht, eds. Soybeans: Improvement, Production, and Uses Agron. Monogr. No. 16, pp. 520-569. ASA-CSSA-SSSA, Madison, WI.

Ray, J. D., L. G. Heatherly, and F. B. Fritschi, 2006: Influence of large amounts of nitrogen on non-irrigated and irrigated soybean. Crop Sci. 46, 52-60.

Sall, K., and T. R. Sinclair, 1991: Soybean genotypic differences in sensitivity of symbiotic nitrogen fixation to soil dehydration. Plant Soil 133, 31-37.

SAS Institute, 2002. SAS Proprietary Software Version 9.2. SAS Inst., Cary, NC.

Serraj, R., and T. R. Sinclair, 1997: Variation among soybean cultivars in nitrogen fixation response to drought. Agron. J. 89, 963-969.

Serraj, R., T. R. Sinclair, and L. C. Purcell, 1999: Symbiotic $\mathrm{N}_{2}$ fixation response to drought. J. Exp. Bot. 50, 143-155.

de Silva, M., L. C. Purcell, and C. A. King, 1996: Soybean petiole ureide response to water deficits and decreased transpiration. Crop Sci. 36, 611-616.

Sinclair, T. R., 1986: Water and nitrogen limitations in soybean grain production. I. Model development. Field Crops Res. 15, 125-141.

Sinclair, T. R., and R. Serraj, 1995: Legume nitrogen fixation and drought. Nature 378, 344.

Sinclair, T. R., L. C. Purcell, C. A. King, C. H. Sneller, P. Chen, and V. Vadez, 2007: Drought tolerance and yield increase of soybean resulting from improved symbiotic $\mathrm{N}_{2}$ fixation. Field Crops Res. 101, 68-71.

Sloane, R. J., R. P. Patterson, and T. E. Jr Carter, 1990: Field drought tolerance of a soybean plant introduction. Crop Sci. 30, 118-123.

Specht, J. E., J. H. Williams, and C. J. Weidenbenner, 1986: Differential responses of soybean genotypes subjected to a seasonal soil water gradient. Crop Sci. 26, 922-934.

Specht, J. E., D. J. Hume, and S. V. Kumudini, 1999: Soybean yield potential - a genetic and physiological perspective. Crop Sci. 39, 1560-1570.

Vadez, V., T. R. Sinclair, and R. Serraj, 2000: Asparagine and ureide accumulation in nodules and shoots as feedback inhibitors of $\mathrm{N}_{2}$ fixation in soybean. Physiol. Plant. 110, 215-223. 